\title{
Hubungan Tutupan Lahan Terhadap Ketersediaan Air di Kecamatan Kanigoro Kabupaten Blitar
}

\author{
Trisno Widodo \\ Program Studi Teknik Sipil, Universitas Nahdlatul Ulama Blitar, Indonesia \\ Email: trisno_widodo@yahoo.com
}

\begin{tabular}{l} 
Tersedia Online di \\
\hline http://www.jurnal.unublitar.ac.id/i \\
ndex.php/briliant
\end{tabular}

\begin{tabular}{l}
\hline Sejarah Artikel \\
\hline Diterima pada 9 Agustus 2020 \\
Disetujui pada 12 November 2020 \\
Dipublikasikan pada 30 November \\
2020 \\
Hal. $851-864$
\end{tabular}

\begin{tabular}{l}
\hline Kata Kunci: \\
\hline Tutupan lahan; Kebutuhan air; \\
Ketersediaan air
\end{tabular}

\section{DOI:}

http://dx.doi.org/10.28926/briliant. v3i4.535

\begin{abstract}
Abstrak: Perubahan tutupan lahan yang semula merupakan lahan terbuka yang berubah menjadi kawasan terbangun yang kedap air dapat menyebabkan meningkatnya debit aliran air permukaan. Seiring laju pembangunan dan perubahan pemanfaatan lahan maka semakin mengurangi daerah terbuka sebagai daerah resapan air. Sedangkan kebutuhan akan air semakin meningkat seiring dengan laju pertumbuhan penduduk. Kecamatan Kanigoro pada 5 Januari 2010 ditetapkan sebagai ibukota Kabupaten Blitar mengalami percepatan perubahan pemanfaatan lahan pedesaan menjadi daerah perkotaan yang mempunyai ciri khas mayoritas pemanfaatan lahannya berupa lahan terbangun. Untuk itu perlu dilakukan kajian hubungan tutupan lahan terhadap ketersediaan air di Kecamatan Kanigoro Kabupaten Blitar dengan menggunakan metode analisis pemanfaatan lahan, kebutuhan air, dan ketersediaan air berdasarkan input dan output air di wilayah Kecamatan Kanigoro, Kabupaten Blitar. Berdasarkan hasil penelitian, maka terdapat wilayah di Kecamatan Kanigoro yang volume ketersediaan air tanahnya akibat adanya perubahan
\end{abstract} penggunaan lahan dari lahan terbuka ke lahan terbangun dan meningkatnya kebutuhan air bersih. Hasil dari penelitian ini dapat menjadi rekomendasi penatagunaan lahan sebagai daerah imbuhan untuk membantu meningkatkan kemampuan tanah meresapkan air lebih lama.

\section{PENDAHULUAN}

Air tanah adalah air yang terdapat pada lapisan akuifer yang merupakan lapisan tanah di bawah permukaan bumi yang terdiri dari lapisan batuan dan partikel tanah yang tidak terkonsolidasi (Indarto, 2010). Keberadaan air tanah ini sangat bergantung pada seberapa besar air di permukaan yang dapat masuk dalam recharge area untuk mengisi tanah atau batuan yang menjadi lapisan pengandung air serta air tanah yang keluar ke permukaan baik secara alamiah melalui mata air atau air artesis ataupun melalui sumur-sumur gali atau bor. Pemanfaatan air tanah sebagai sumber air ini juga dipicu dengan adanya keterbatasan penyediaan dan pelayanan air bersih. Sehingga untuk memenuhi kebutuhan air bersih, sebagian besar penduduk di Kabupaten Blitar masih menggunakan air sumur. Semakin marak dan meningkatnya pemanfaatan air tanah ini serta berubahnya pemanfaatan lahan menjadi lahan terbangun dapat menyebabkan berkurangnya ketersediaan air tanah. Kecamatan Kanigoro berdasarkan Peraturan Pemerintah Nomor 3 Tahun 2010 tanggal 5 Januari 2010 ditetapkan sebagai ibukota Kabupaten Blitar mengalami perubahan pemanfaatan lahan pedesaan menjadi daerah perkotaan. Perkembangan kota yang demikian pesat terutama berubahnya pemanfaatan lahan dapat merugikan keadaan kota itu sendiri seperti hilangnya resapan air 
(Widharyatmo, 2010). Dengan hilangnya daerah resapan air ini maka dapat mengakibatkan berkurangnya infiltrasi air ke dalam tanah serta dapat menyebabkan banjir akibat meningkatnya limpasan air hujan di permukaan. Belum lagi dengan semakin merebaknya pemanfaatan air tanah oleh penduduk dan kalangan usaha untuk memenuhi kebutuhan air bersih. Kondisi ini berakibat semakin berkurangnya potensi air tanah dalam akifer karena pengambilan yang terus menerus tanpa diimbangi dengan proses infiltrasi air ke dalam tanah akibat berkurangnya resapan air. Untuk itu perlu dilakukan kajian hubungan tutupan lahan terhadap ketersediaan air di Kecamatan Kanigoro Kabupaten Blitar sebagai masukan untuk penataan pengembangan ibukota kabupaten dalam penatagunaan lahan dan pengaturan pemanfaatan air tanah. Penataan pemanfaatan lahan dan tata ruang air dilakukan dari daerah resapan air (recharge area) sampai daerah keluarnya air tanah atau daerah pengambilan air tanah sesuai siklus hidrologi dan model air tanah dengan tujuan menjaga keseimbangan perkembangan kota (Harris, 2010).

\section{METODE}

Penelitian ini menggunakan metode analisis numerik dan deskripsi berdasarkan pada peta citra satelit dan data statistik yang diolah dengan menggunakan metode analisa daya dukung air. Secara umum teknik analisis data yang penulis lakukan sebagai berikut:

1. Analisis Perubahan Pemanfaatan Lahan

Perubahan pemanfaatan lahan didapatkan dengan membandingkan hasil analisis peta citra satelit penggunaan lahan tahun 2002 dan 2018.

2. Analisis Kemampuan Lahan

Kemampuan lahan dihitung untuk mengetahui fungsi peruntukan suatu lahan berdasarkan Peraturan Menteri Pekerjaan Umum No. 20 Tahun 2007 tentang Pedoman Teknik Analisis Aspek Fisik dan Lingkungan, Ekonomi, serta Sosial Budaya dalam Penyusunan Rencana Tata Ruang

3. Perhitungan Ketersediaan Air

Ketersediaan air sangat dipengaruhi oleh koefisien limpasan air yang diperoleh dari data pemanfaatan lahan dan curah hujan dengan menggunakan perhitungan metode rasional, yaitu :

$\mathrm{C}=\sum(\mathrm{cix} \mathrm{Ai}) / \sum \mathrm{Ai}$

$\mathrm{R}=\sum \mathrm{Ri} / \mathrm{m}$

$\mathrm{SA}=10 \times \mathrm{C} \times \mathrm{R} \times \mathrm{A}$

Keterangan :

$\mathrm{SA}=$ Ketersediaan air (m3/tahun)

$\mathrm{C}=$ Koefisien limpasan tertimbang

$\mathrm{Ci}=$ Koefisien limpasan penggunaan lahan $\mathrm{i}$

$\mathrm{Ai}=$ Luas penggunaan lahan berdasarkan data citra satelit

$\mathrm{R}$ = Rata-rata curah hujan tahunan wilayah ( $\mathrm{mm} /$ tahun) dari data $\mathrm{BMKG}$

$\mathrm{Ri}=$ Curah hujan tahunan pada stasiun $\mathrm{i}$

$\mathrm{m}=$ Jumlah stasiun pengamatan curah hujan

$\mathrm{A}=$ Luas wilayah

$10=$ Faktor konversi dari mm.ha menjadi $\mathrm{m}^{3}$ 
Tabel 1. Koefisien Limpasan

\begin{tabular}{|c|l|c|}
\hline No & \multicolumn{1}{|c|}{ Deskripsi Permukaan } & $\mathrm{Ci}$ \\
\hline 1. & Kota, jalan aspal, atap genteng & $0,7-0,9$ \\
\hline 2. & Kawasan industri & $0,5-0,9$ \\
\hline 3. & Permukiman multi unit, pertokoan & $0,6-0,7$ \\
\hline 4. & Kompleks perumahan & $0,4-0,6$ \\
\hline 5. & Villa & $0,3-0,5$ \\
\hline 6. & Taman, pemakaman & $0,1-0,3$ \\
\hline 7. & Pekarangan tanah berat : & \\
& a. >7\% & $0,25-0,35$ \\
& b. 2-7\% & $0,18-0,22$ \\
& c. $<2 \%$ & $0,13-0,17$ \\
\hline 8. & Pekarangan tanah berat : & \\
& a. >7\% & $0,15-0,2$ \\
& b. 2-7\% & $0,10-0,15$ \\
& c. $<2 \%$ & $0,05-0,10$ \\
\hline 9. & Lahan berat & 0,40 \\
\hline 10. & Padang rumput & 0,35 \\
\hline 11. & Lahan budidaya pertanian & 0,30 \\
\hline 12. & Hutan produksi & 0,18 \\
\hline
\end{tabular}

(Sumber : Peraturan Menteri Negara Lingkungan Hidup Nomor 17 Tahun 2009)

4. Perhitungan Kebutuhan Air.

Perhitungan kebutuhan air total menggunakan pendekatan prioritas penggunaan air pada 3 (tiga) kelompok besar pengguna air (Putranto dan Kusuma, 2010), yaitu:

a. Kebutuhan air domestik total. Acuan dasar kebutuhan air untuk penduduk di perkotaan sebesar 120L/hari/kapita serta penduduk pedesaan membutuhkan 60L/hari/kapita.

- Kebutuhan air domestik pedesaan, dengan rumus:

$\Sigma$ penduduk x $365 \times 60 \mathrm{~L}$

- Kebutuhan air domestik perkotaan, dengan rumus:

$\Sigma$ penduduk x $365 \times 120 \mathrm{~L}$

Selain kebutuhan air penduduk juga ditambahkan dengan perhitungan untuk kebutuhan fasilitas umum/sosial sebesar 5\% dari kebutuhan domestik dan kebocoran maksimal 20\% dari kebutuhan domestik.

b. Kebutuhan air sektor pertanian. Kebutuhan air sektor pertanian didapatkan dari perhitungan kebutuhan air pertanian, peternakan dan perikanan, yaitu :

Dsptn $=$ Dptn + Dptk + Dpik

Dimana:

Dsptn = Kebutuhan air sektor pertanian

Dptn $\quad=$ Kebutuhan air pertanian

Dptk = Kebutuhan air peternakan

Dpik = Kebutuhan air perikanan (kolam ikan)

Kebutuhan air untuk pertanian ini dipergunakan dalam waktu satu tahun yang dihitung berdasarkan luas sawah dengan standar kebutuhan air rata- 
rata sama sebesar $1 \mathrm{~L} / \mathrm{det} / \mathrm{ha}$ dengan penggunaan perhitungan musim tanam selama 120 hari/musim sehingga didapat hasil :

\section{$\mathrm{A}=\mathrm{L} \times 3600 \mathrm{det} / \mathrm{jam} \times 24$ jam/hari $\times 120$ hari/musim $\times$ a}

Sedangkan untuk kebutuhan air peternakan dapat dihitung dari perkalian jumlah ternak yang ada dengan kebutuhan air untuk tiap jenis ternak. Standar kebutuhan air untuk ternak sebagaimana Tabel 2 berikut :

Tabel 2. Kebutuhan Air Untuk Ternak

\begin{tabular}{|c|l|c|}
\hline No & \multicolumn{1}{|c|}{ Jenis Ternak } & $\begin{array}{c}\text { Kebutuhan Air } \\
\text { (L/ekor/hari) }\end{array}$ \\
\hline 1 & Sapi/kerbau & 40 \\
\hline 2 & Domba/kambing & 5 \\
\hline 3 & Babi & 6 \\
\hline 4 & Unggas & 0,6 \\
\hline \multicolumn{2}{|c|}{ (Sumber : SNI 19-6828.1-2002) }
\end{tabular}

Untuk sektor perikanan, kebutuhan airnya untuk mengisi kolam pada saat awal tanam dan kebutuhan untuk penggantian air, yaitu standarnya sebesar $7 \mathrm{~mm} / \mathrm{hari} / \mathrm{m}^{2}$ (Bappenas, 2006).

c. Kebutuhan Air Total. Kebutuhan air total merupakan penjumlahan dari kebutuhan air domestik, kebutuhan air sektor industri dan kebutuhan air sektor pertanian, yaitu :

$\mathbf{D}_{\mathrm{A}}=$ Ddms + Dptn + Dids

Dimana

$\mathrm{D}_{\mathrm{A}} \quad=$ Kebutuhan air total

Ddms = Kebutuhan air domestik perkotaan dan pedesaan

Dptn = Kebutuhan air sektor pertanian

Dids = Kebutuhan air industri

5. Perhitungan daya dukung air. Daya dukung air diperoleh dari ketersediaan air (SA) dibandingkan dengan kebutuhan air (DA), yaitu :

- Bila SA > DA, maka daya dukung air dalam keadaan surplus;

- Bila SA < DA, maka daya dukung air dalam keadaan defisit atau terlampaui.

\section{HASIL}

\section{Hasil Analisis Perubahan Pemanfaatan Lahan Tahun 2002 dan 2018}

Pemanfaatan lahan di Kecamatan Kanigoro berdasarkan hasil interpretasi citra satelit tahun 2002 dan 2018 adalah sebagai Tabel 3 berikut :

Tabel 3. Perbandingan Luas Pemanfaatan Lahan Kecamatan Kanigoro

\begin{tabular}{|c|c|r|r|r|r|r|r|r|r|}
\hline \multirow{2}{*}{ No } & \multirow{2}{*}{ Uraian } & \multicolumn{7}{|c|}{ Luas Pemanfaatan Lahan (Ha) } \\
\cline { 3 - 10 } & $\begin{array}{c}\text { Badan } \\
\text { Air }\end{array}$ & Hutan & Kebun & $\begin{array}{c}\text { Lahan } \\
\text { Kosong }\end{array}$ & Permukiman & Sawah & Perkebunan & Total \\
\hline 1 & 2002 & 147 & 48 & 246 & 12 & 2.004 & 3.098 & 0 & 5.555 \\
\hline 2 & 2018 & 0 & 81 & 1.051 & 0 & 2.305 & 2.118 & 0 & 5.555 \\
\hline
\end{tabular}

Berdasarkan Tabel 3 tersebut maka terlihat bahwa pada tahun 2002, pemanfaatan lahan terluas sampai terkecil adalah berupa sawah dengan luas 3.098 ha $(55,77 \%)$, 
permukiman 2.004 ha (36,07\%), kebun 246 ha (4,42\%), badan air 147 ha (2,65\%), Hutan 48 ha $(0,87 \%)$, lahan kosong 12 ha $(0,21 \%)$. Sedangkan apabila dilihat luas pemanfaatan lahan tahun 2018 maka terjadi perubahan luas masing-masing pemanfaatan lahan dari yang terluas sampai terkecil adalah berupa lahan permukiman seluas 2.305 ha $(41,49 \%)$, sawah 2.118 ha $(38,13 \%)$, kebun 1.051 ha $(18,92 \%)$, hutan 81 ha $(1,46 \%)$.

\section{Hasil Analisis Kemampuan Lahan}

Secara keseluruhan wilayah Kabupaten Blitar termasuk dalam wilayah lereng kurang dari $15 \%$. Jika dilihat peta kelerengan, maka Kecamatan Kanigoro yang berada di bagian tengah Kabupaten Blitar termasuk dalam kelerengan kurang dari 2\%, maka ketersediaan air berdasarkan kemampuan lahan di Kecamatan Kanigoro termasuk katagori ketersediaan air tinggi dengan nilai 1 dari rentang nilai $1-5$.

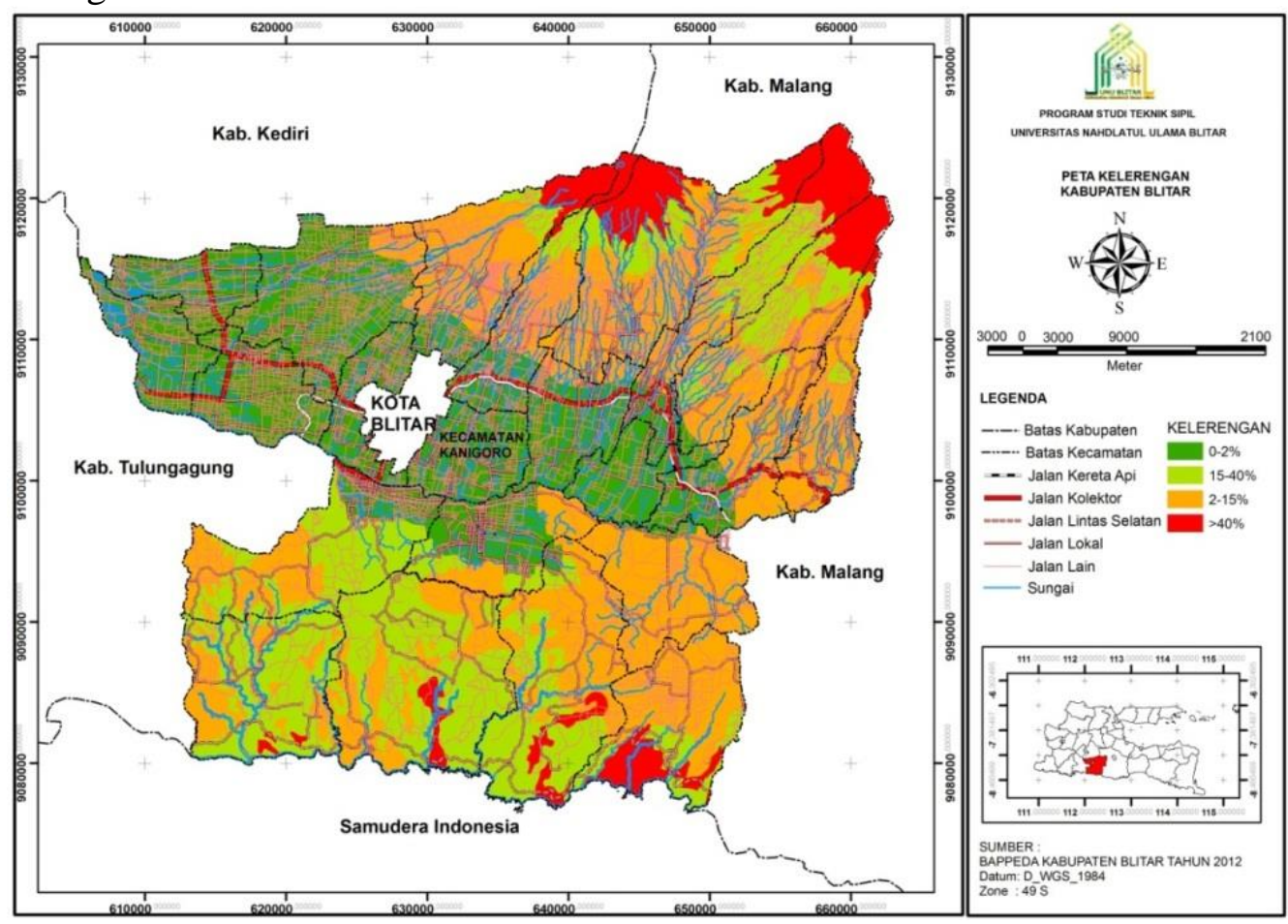

Gambar 1. Peta Kelerengan Kabupaten Blitar (Sumber : Bappeda Kab. Blitar, 2012)

\section{Hasil Analisis Ketersediaan Air}

Perhitungan ketersediaan air dihitung menggunakan rumus metode rasional. Berdasarkan hasil analisis penggunaan lahan menggunakan citra satelit maka hanya terdapat 4 penggunaan lahan di Kecamatan Kanigoro dari 7 katagori penggunaan lahan yang penulis pergunakan, yaitu berupa hutan, kebun, permukiman dan sawah. Penggunaan lahan terbesar di Kecamatan Kanigoro pada tahun 2018 adalah berupa lahan permukiman 41,49\% (2.305 ha) diikuti lahan sawah 38,13\% (2.118 ha). Berdasarkan katagori deskripsi permukaan lahan sesuai dengan Peraturan Menteri Negara Lingkungan Hidup Nomor 17 Tahun 2009 untuk mendapatkan koefisien limpasan, maka penggunaan lahan di Kecamatan Kanigoro dikelompokkan menjadi 3 (tiga), yaitu permukiman, lahan budidaya pertanian (untuk kebun dan sawah) serta hutan produksi. 


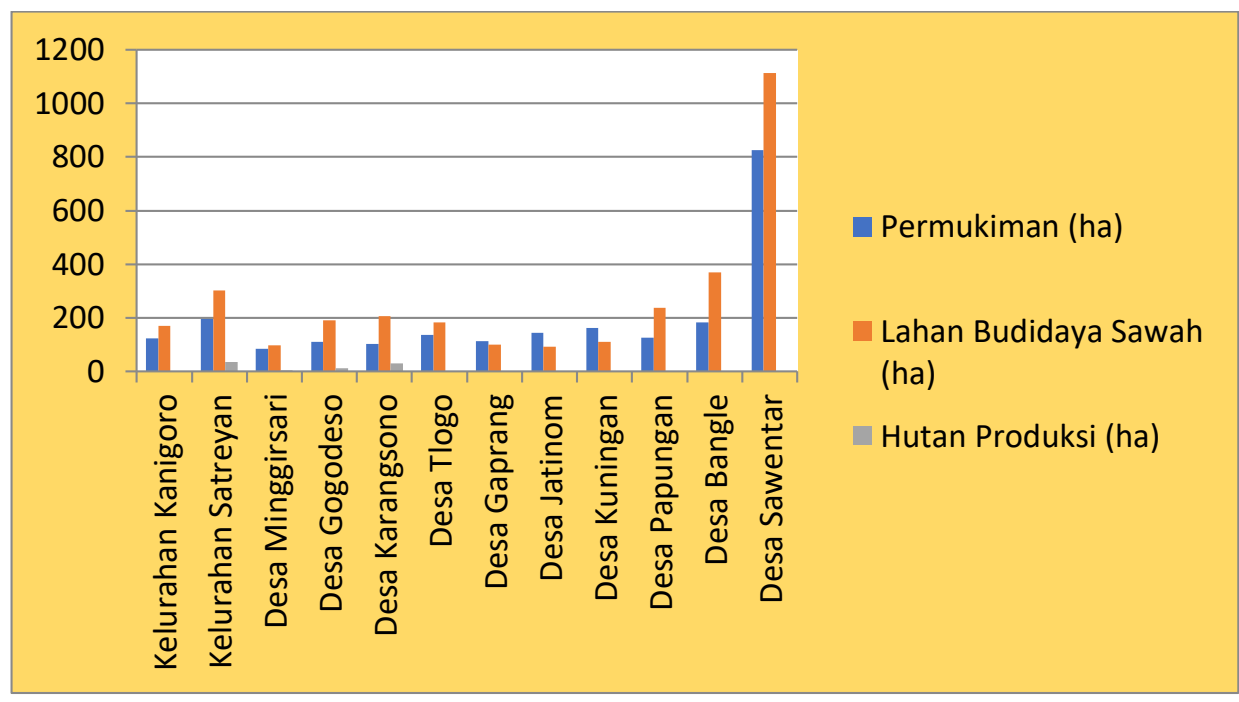

Gambar 2. Deskripsi Permukaan Lahan Kecamatan Kanigoro Tahun 2018

Melalui hasil pengelompokan tersebut, maka penulis dapat menentukan koefisien limpasan dan menghitung koefisien limpasan tertimbang menggunakan metode rasional Berdasarkan Gambar 2, maka nampak bahwa permukaan lahan terbesar adalah berupa lahan budidaya pertanian yang terdiri dari lahan sawah dan kebun $57,05 \%$. Dengan menggunakan perhitungan metode rasional maka didapatkan hasil perkalian koefisien permukaan dan luas lahan serta koefisien limpasan tertimbang (C) Kecamatan Kanigoro tahun 2018 sebesar 0,46.

Curah hujan wilayah Kecamatan Kanigoro diukur oleh 1 (satu) stasiun pengukuran curah hujan dengan rata-rata aljabar curah hujan tahunannya (R), yaitu $1.604 \mathrm{~mm} / \mathrm{tahun}$.

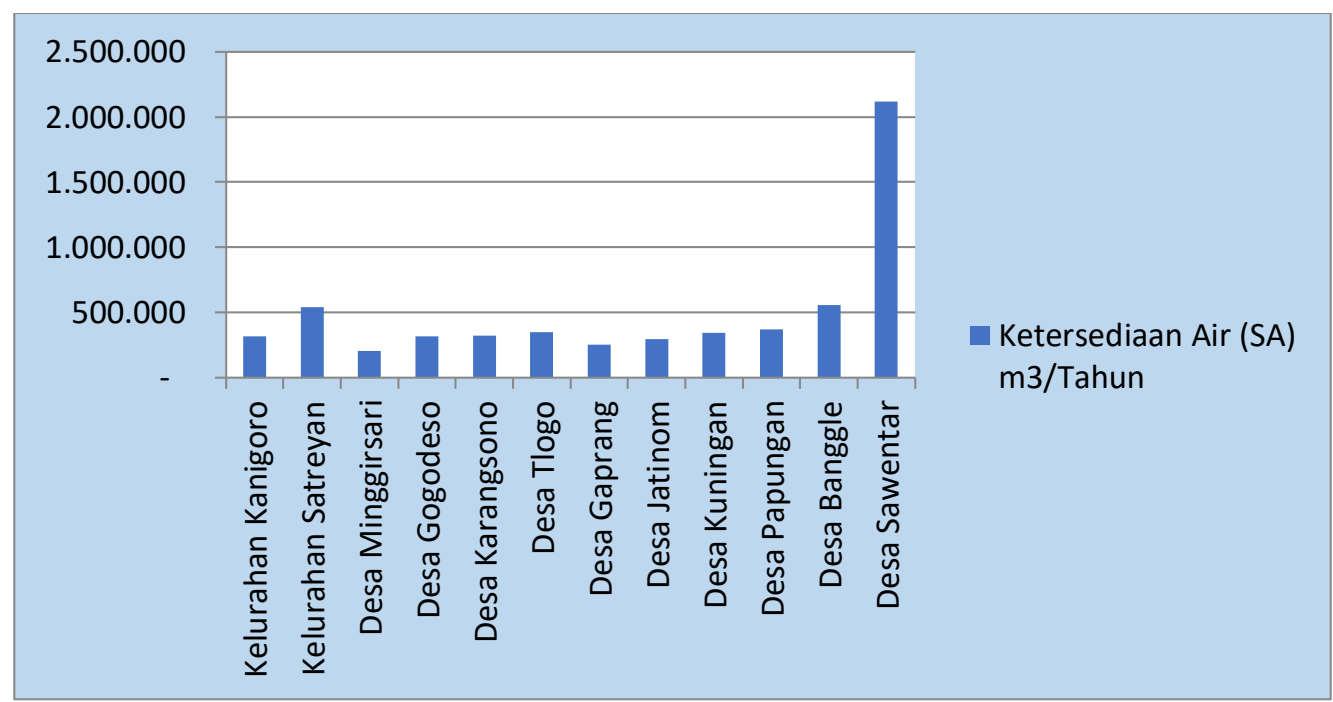

Gambar 3. Ketersediaan Air Kecamatan Kanigoro Tahun 2018

Ketersediaan air merupakan hasil dari perkalian koefisien limpasan tertimbang, rata-rata alajabar curah hujan tahunan dan luas lahan yang dikalikan 10. Berdasarkan hasil perhitungan ketersediaan air rumus 3, maka didapatkan hasil bahwa ketersediaan air di Kecamatan Kanigoro pada Tahun 2018 sebesar $5.982 .612 \mathrm{~m}^{3} /$ tahun. Komposisi ketersediaan air kawasan perkotaan sebesar 
$14,32 \%$ dan kawasan pedesaan sebesar 85,68\%. Dengan ketersediaan air terbesar berada di Desa Sawentar 35,39\% (2.117.169 $\left.\mathrm{m}^{3} / \mathrm{tahun}\right)$ dan ketersediaan air terkecil di Desa Minggirsari 3,44\% (205.817 $\mathrm{m}^{3} /$ tahun).

\section{Hasil Analisis Kebutuhan Air}

Kebutuhan air total merupakan penjumlahan dari kebutuhan air domestik total, industri dan sektor pertanian. Kebutuhan air domestik total dapat diperoleh dengan mempergunakan kebutuhan air per penduduk di perkotaan, pedesaan serta kebutuhan air fasilitas umum/sosial sebesar 5\% dari kebutuhan domestik dan kebocoran maksimal 20\% dari kebutuhan domestik.

Tabel 4. Kebutuhan Air Domestik Kecamatan Kanigoro Tahun 2018

\begin{tabular}{|c|c|c|c|c|c|c|}
\hline No. & Kelurahan / Desa & $\begin{array}{c}\text { Jumlah } \\
\text { Penduduk }\end{array}$ & $\begin{array}{c}\text { Kebutuhan } \\
\text { Air Domestik } \\
\text { (m3/tahun) }\end{array}$ & $\begin{array}{c}\text { Kebutuhan Air } \\
\text { Fasum/Fasos } \\
\text { (m3/tahun) }\end{array}$ & $\begin{array}{c}\text { Kebocoran } \\
\text { Air } \\
\text { (m3/tahun) }\end{array}$ & $\begin{array}{c}\text { Kebutuhan } \\
\text { Air Domestik } \\
\text { Total } \\
\text { (m3/tahun) }\end{array}$ \\
\hline & Kawasan Perkotaan & & & & & \\
\hline 1 & Kelurahan Kanigoro & 5552 & 243.178 & 12.159 & 48.636 & 303.972 \\
\hline \multirow[t]{3}{*}{2} & Kelurahan Satreyan & 8316 & 364.241 & 18.212 & 72.848 & 455.301 \\
\hline & Jumlah Perkotaan & 13868 & 607.418 & 30.371 & 121.484 & 759.273 \\
\hline & Kawasan Pedesaan & & & & & \\
\hline 3 & Desa Minggirsari & 3875 & 84.863 & 4.243 & 16.973 & 106.078 \\
\hline 4 & Desa Gogodeso & 5326 & 116.639 & 5.832 & 23.328 & 145.799 \\
\hline 5 & Desa Karangsono & 5712 & 125.093 & 6.255 & 25.019 & 156.366 \\
\hline 6 & Desa Tlogo & 7204 & 157.768 & 7.888 & 31.554 & 197.210 \\
\hline 7 & Desa Gaprang & 5551 & 121.567 & 6.078 & 24.313 & 151.959 \\
\hline 8 & Desa Jatinom & 5615 & 122.969 & 6.148 & 24.594 & 153.711 \\
\hline 9 & Desa Kuningan & 3413 & 74.745 & 3.737 & 14.949 & 93.431 \\
\hline 10 & Desa Papungan & 6379 & 139.700 & 6.985 & 27.940 & 174.625 \\
\hline 11 & Desa Banggle & 8074 & 176.821 & 8.841 & 35.364 & 221.026 \\
\hline 12 & Desa Sawentar & 13203 & 289.146 & 14.457 & 57.829 & 361.432 \\
\hline & Jumlah Pedesaan & 64352 & 1.409 .309 & 70.465 & 281.862 & 1.761 .636 \\
\hline & Total & 78220 & 2.016.727 & 100.836 & 403.345 & 2.520 .909 \\
\hline
\end{tabular}

Berdasarkan hasil perhitungan Tabel 4 dengan menggunakan rumus 5 dan 6, maka kebutuhan air domestik total Kecamatan Kanigoro pada tahun 2018 adalah sebesar 2.520.909 m3/tahun dengan komposisi kebutuhan air kawasan perkotaan sebesar 30,12\% dan kawasan pedesaan sebesar 69,88\%. Kebutuhan air terbanyak ada di Kelurahan Satreyan 18,06\% (455.301 m3/tahun) dan yang terkecil di Desa Kuningan 3,71\% (93.431 m3/tahun).

\section{Hasil Analisis Kebutuhan Air Sektor Pertanian}

Kebutuhan air sektor pertanian dapat diperoleh dengan mempergunakan kebutuhan air persawahan, peternakan dan perikanan (kolam ikan). Berdasarkan perhitungan mempergunakan luas sawah masing-masing wilayah sebagaimana Tabel 5 dan dengan asumsi musim tanam selama 120 hari/musim, maka didapatkan hasil kebutuhan air untuk persawahan di Kecamatan Kanigoro pada 
tahun 2018 sebesar 21,957,889 $\mathrm{m}^{3} /$ tahun dengan komposisi kebutuhan air persawahan kawasan perkotaan sebesar 18,27 \% dan kawasan pedesaan 81,73\%. Kebutuhan air terbanyak ada di Desa Sawentar 31,01\% $\left(6,808,855 \mathrm{~m}^{3} / \mathrm{tahun}\right)$ dan terkecil di Desa Minggirsari 1,42\% (312,416 $\mathrm{m}^{3} /$ tahun).

Tabel 5. Luas Sawah dan Kebutuhan Air Pertanian Kecamatan Kanigoro Tahun 2018

\begin{tabular}{|r|l|r|r|}
\hline No & Desa / Kelurahan & $\begin{array}{c}\text { Luas Sawah } \\
(\mathrm{Ha})\end{array}$ & $\begin{array}{c}\text { Kebutuhan Air } \\
\text { (m3/Tahun) }\end{array}$ \\
\hline & Kawasan Perkotaan & & \\
\hline 1 & Kelurahan Kanigoro & 140 & 1.449 .546 \\
\hline 2 & Kelurahan Satreyan & 247 & 2.562 .808 \\
\hline & Jumlah Perkotaan & $\mathbf{3 8 7}$ & $\mathbf{4 . 0 1 2 . 3 5 4}$ \\
\hline & & & \\
\hline & Kawasan Pedesaan & & \\
\hline 3 & Desa Minggirsari & 30 & 312.416 \\
\hline 4 & Desa Gogodeso & 116 & 1.206 .525 \\
\hline 5 & Desa Karangsono & 130 & 1.347 .399 \\
\hline 6 & Desa Tlogo & 125 & 1.293 .760 \\
\hline 7 & Desa Gaprang & 82 & 851.153 \\
\hline 8 & Desa Jatinom & 68 & 709.536 \\
\hline 9 & Desa Kuningan & 91 & 939.502 \\
\hline 10 & Desa Papungan & 141 & 1.466 .374 \\
\hline 11 & Desa Bangle & 290 & 3.010 .015 \\
\hline 12 & Desa Sawentar & 657 & 6.808 .855 \\
\hline & Jumlah Pedesaan & $\mathbf{1 7 3 1}$ & $\mathbf{1 7 . 9 4 5 . 5 3 5}$ \\
\hline & Total & $\mathbf{2 1 1 8}$ & $\mathbf{2 1 . 9 5 7 . 8 8 9}$ \\
\hline & & \multicolumn{2}{|c|}{} \\
\hline
\end{tabular}

Berdasarkan perhitungan mempergunakan Tabel 2 dengan dasar jumlah ternak masing-masing wilayah, maka didapatkan hasil kebutuhan air untuk peternakan di Kecamatan Kanigoro pada tahun 2018 sebesar $401.207 \mathrm{~m}^{3} /$ tahun sebagaimana nampak pada Tabel 6 dengan kebutuhan terbanyak adalah untuk ternak unggas, yang terdiri dari ayam kampung, ayam ras, ayam pedaging, dan itik. Komposisi kebutuhan air peternakan kawasan perkotaan sebesar 10,62\% dan kawasan pedesaan 89,38\%. Kebutuhan air terbanyak ada di Desa Sawentar $24,85 \%$ (99.648 $\mathrm{m}^{3} /$ tahun) dan terkecil di Desa Kuningan 1,03\% (4.130 $\mathrm{m}^{3} /$ tahun).

Berdasarkan perhitungan mempergunakan luas kolam masing-masing wilayah dan dengan asumsi kebutuhan air untuk mengisi kolam pada saat awal tanam dan kebutuhan untuk penggantian air, yaitu standarnya sebesar 7 $\mathrm{mm} / \mathrm{hari} / \mathrm{m}^{2}$ (Bappenas, 2006), maka didapatkan hasil kebutuhan air untuk perikanan di Kecamatan Kanigoro pada tahun 2018 sebesar 0,046 m³/tahun sebagaimana Tabel 7 dengan kolam ikan seluas 1,8 ha. Penjumlahan hasil perhitungan kebutuhan air persawahan, peternakan dan perikanan maka penulis mendapatkan kebutuhan air sektor pertanian di Kecamatan Kanigoro tahun 2018 sebesar 620.786,046 $\mathrm{m}^{3} /$ tahun. Komposisi kebutuhan air sektor pertanian kawasan perkotaan sebesar $18,14 \%$ dan kawasan pedesaan $81,86 \%$. Kebutuhan 
air terbanyak ada di Desa Sawentar 30,90\% (6.908.503 $\mathrm{m}^{3} /$ tahun) dan terkecil di Desa Minggirsari 1,59\% (354.819 $\mathrm{m}^{3} /$ tahun).

Tabel 6. Jumlah Ternak dan Kebutuhan Air PeternakanDi Kecamatan Kanigoro Tahun 2018

\begin{tabular}{|c|c|c|c|c|c|c|c|c|c|c|}
\hline \multirow[b]{2}{*}{ No } & \multirow[b]{2}{*}{ Lokasi } & \multicolumn{4}{|c|}{ Jumlah Ternak (Ekor) } & \multicolumn{5}{|c|}{ Kebutuhan Air (m3/Tahun) } \\
\hline & & $\begin{array}{c}\text { Sapi, Kerbau, } \\
\text { Kuda }\end{array}$ & $\begin{array}{l}\text { Domba, } \\
\text { Kambing }\end{array}$ & Kelinci & Unggas & $\begin{array}{c}\text { Sapi, Kerbau, } \\
\text { Kuda }\end{array}$ & $\begin{array}{l}\text { Domba, } \\
\text { Kambing }\end{array}$ & Kelinci & Unggas & Total \\
\hline 1 & 2 & 3 & 4 & 5 & 6 & 7 & 8 & 9 & 10 & 11 \\
\hline 1 & Kelurahan Kanigoro & 144 & 192 & 23 & 51.877 & 2.102 & 350 & 5 & 11.361 & 13.819 \\
\hline 2 & Kelurahan Satreyan & 981 & 385 & 54 & 62.707 & 14.323 & 703 & 12 & 13.733 & 28.770 \\
\hline 3 & Desa Minggirsari & 481 & 177 & 44 & 160.037 & 7.023 & 323 & 10 & 35.048 & 42.403 \\
\hline 4 & Desa Gogodeso & 633 & 438 & 58 & 72.815 & 9.242 & 799 & 13 & 15.946 & 26.000 \\
\hline 5 & Desa Karangsono & 523 & 409 & 43 & 103.394 & 7.636 & 746 & 9 & 22.643 & 31.035 \\
\hline 6 & Desa Tlogo & 324 & 475 & 46 & 52.012 & 4.730 & 867 & 10 & 11.391 & 16.998 \\
\hline 7 & Desa Gaprang & 586 & 309 & 32 & 29.160 & 8.556 & 564 & 7 & 6.386 & 15.513 \\
\hline 8 & Desa Jatinom & 397 & 378 & 48 & 325.105 & 5.796 & 690 & 11 & 71.198 & 77.695 \\
\hline 9 & Desa Kuningan & 67 & 72 & 7 & 13.785 & 978 & 131 & 2 & 3.019 & 4.130 \\
\hline 10 & Desa Papungan & 578 & 381 & 40 & 45.150 & 8.439 & 695 & 9 & 9.888 & 19.031 \\
\hline 11 & Desa Banggle & 884 & 583 & 66 & 54.798 & 12.906 & 1.064 & 14 & 12.001 & 25.986 \\
\hline 12 & Desa Sawentar & 2.386 & 1.110 & 136 & 286.560 & 34.836 & 2.026 & 30 & 62.757 & 99.648 \\
\hline & Total & 5.598 & 3.799 & 461 & 970.840 & 81.731 & 6.933 & 101 & 212.614 & 301.379 \\
\hline
\end{tabular}

Tabel 7. Luas Kolam Ikan dan Kebutuhan Air Perikanan Di Kecamatan Kanigoro Tahun 2018

\begin{tabular}{|r|l|r|r|r|}
\hline No & \multicolumn{1}{|c|}{ Lokasi } & $\begin{array}{c}\text { Luas } \\
\text { Wilayah }\end{array}$ & $\begin{array}{c}\text { Luas Kolam } \\
\text { Ikan (ha) }\end{array}$ & $\begin{array}{c}\text { Kebutuhan Air } \\
\text { (m3/Tahun) }\end{array}$ \\
\hline 1 & \multicolumn{1}{|c|}{2} & & \multicolumn{1}{c}{3} & 4 \\
\hline & Kawasan Perkotaan & & & \\
\hline 1 & Kelurahan Kanigoro & 292 & 0,095 & 0,0024 \\
\hline 2 & Kelurahan Satreyan & 530 & 0,172 & 0,0044 \\
\hline & Jumlah Perkotaan & 822 & 0,266 & 0,0068 \\
\hline & & & & \\
\hline & Kawasan Pedesaan & & & 0,0015 \\
\hline 3 & Desa Minggirsari & 186 & 0,060 & 0,0026 \\
\hline 4 & Desa Gogodeso & 312 & 0,101 & 0,0028 \\
\hline 5 & Desa Karangsono & 339 & 0,110 & 0,0026 \\
\hline 6 & Desa Tlogo & 318 & 0,103 & 0,0018 \\
\hline 7 & Desa Gaprang & 213 & 0,069 & 0,0020 \\
\hline 8 & Desa Jatinom & 236 & 0,076 & 0,0023 \\
\hline 9 & Desa Kuningan & 274 & 0,089 & 0,0030 \\
\hline 10 & Desa Papungan & 363 & 0,118 & 0,0046 \\
\hline 11 & Desa Banggle & 552 & 0,179 & 0,0161 \\
\hline & Desa Sawentar & 1.940 & 0,629 & 0,0392 \\
\hline & Jumlah Pedesaan & 4.733 & 1,53 & 0,0460 \\
\hline & Total & 5.555 & 1,80 & \\
\hline
\end{tabular}

\section{Hasil Analisis Kebutuhan Air Industri}

Berdasarkan perhitungan mempergunakan jumlah tenaga kerja yang bekerja di sektor industri masing-masing wilayah dengan perhitungan kebutuhan air industri per hari yang digunakan adalah 500 liter / karyawan / hari (Bappenas, 2006), maka didapatkan hasil kebutuhan air untuk industri di Kecamatan Kanigoro pada tahun 2018 sebesar $238.163 \mathrm{~m}^{3} /$ tahun sebagaimana Tabel 8 dengan komposisi kebutuhan air industri kawasan perkotaan sebesar 18,85\% dan kawasan pedesaan 81,15\%. Kebutuhan air terbanyak ada di Desa Sawentar 25,59\% (60.955 $\mathrm{m}^{3} /$ tahun) dan terkecil di Desa Kuningan 2,53\% (6.023 $\mathrm{m}^{3} /$ tahun). 
Tabel 8. Jumlah Tenaga Kerja dan Kebutuhan Air Industri Di Kecamatan Kanigoro Tahun 2018

\begin{tabular}{|r|l|r|r|}
\hline No & \multicolumn{1}{|c|}{ Lokasi } & $\begin{array}{r}\text { Jumlah Tenaga } \\
\text { Kerja Industri }\end{array}$ & $\begin{array}{c}\text { Kebutuhan Air } \\
\left(\mathrm{m}^{3} / \text { Tahun }\right)\end{array}$ \\
\hline & Kawasan Perkotaan & & \\
\hline 1 & Kelurahan Kanigoro & 112 & 20440 \\
\hline 2 & Kelurahan Satreyan & 134 & 24455 \\
\hline & Jumlah Perkotaan & $\mathbf{2 4 6}$ & $\mathbf{4 4 8 9 5}$ \\
\hline & & & \\
\hline & Kawasan Pedesaan & & 9490 \\
\hline 3 & Desa Minggirsari & 52 & 12045 \\
\hline 4 & Desa Gogodeso & 66 & 15878 \\
\hline 5 & Desa Karangsono & 87 & 16060 \\
\hline 6 & Desa Tlogo & 88 & 13688 \\
\hline 7 & Desa Gaprang & 75 & 10220 \\
\hline 8 & Desa Jatinom & 56 & 6022,5 \\
\hline 9 & Desa Kuningan & 33 & 20440 \\
\hline 10 & Desa Papungan & 112 & 28470 \\
\hline 11 & Desa Banggle & 156 & 60955 \\
\hline 12 & Desa Sawentar & 334 & $\mathbf{1 9 3 2 6 8}$ \\
\hline & Jumlah Pedesaan & $\mathbf{1 0 5 9}$ & $\mathbf{2 3 8 1 6 3}$ \\
\hline & Total & $\mathbf{1 3 0 5}$ & \\
\hline
\end{tabular}

\section{Hasil Analisis Kebutuhan Air Total}

Kebutuhan air total Kecamatan Kanigoro tahun 2018 didapatkan dari penjumlahan kebutuhan air domestik total, sektor pertanian dan industri. Berdasarkan perhitungan menggunakan rumus 9, maka didapatkan hasil kebutuhan air total di Kecamatan Kanigoro pada tahun 2018 sebesar 25.117.987 m3/tahun dengan komposisi kebutuhan air total kawasan perkotaan sebesar $18,09 \%$ dan kawasan pedesaan $81,91 \%$. Kebutuhan air terbanyak ada di Desa Sawentar 29,19\% (7.330.890 m3/tahun) dan terkecil di Desa Minggirsari 2,05\% (470.387 m3/tahun). Kebutuhan air yang paling besar terdapat pada sektor pertanian sebesar $89,02 \%$ (22.358.916 m3/tahun).

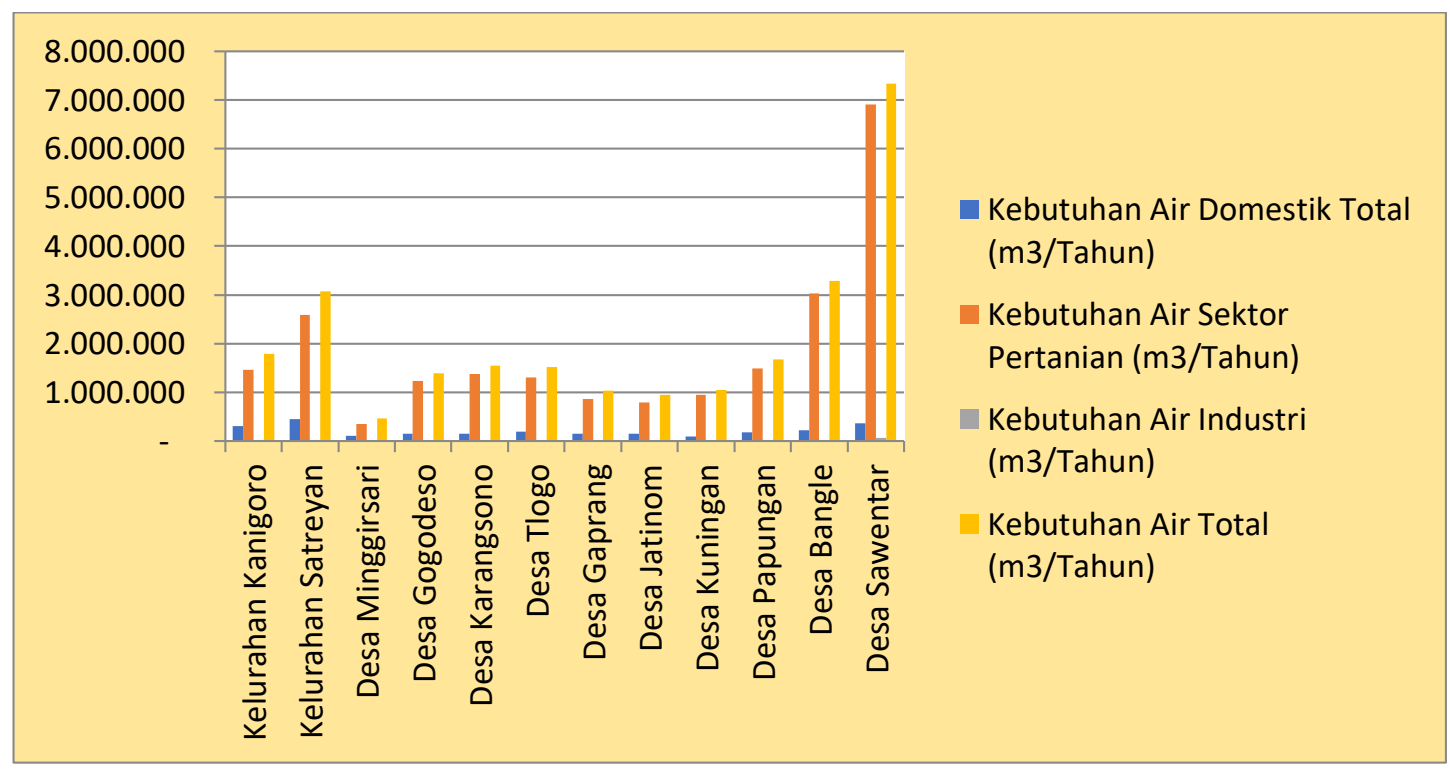

Gambar 4. Kebutuhan Air Total Kecamatan Kanigoro Tahun 2018

860 BRILIANT: Jurnal Riset dan Konseptual

Volume 5 Nomor 4, November 2020 


\section{Hasil Analisis Daya Dukung Air}

Daya dukung air diperoleh dari ketersediaan air $\left(\mathrm{S}_{\mathrm{A}}\right)$ dibandingkan dengan kebutuhan air $\left(\mathrm{DA}_{\mathrm{A}}\right)$, yaitu:

- Bila $S_{A}>D_{A}$, maka daya dukung air dalam keadaan surplus;

- Bila $\mathrm{S}_{\mathrm{A}}<\mathrm{DA}_{\mathrm{A}}$, maka daya dukung air dalam keadaan defisit atau terlampaui.

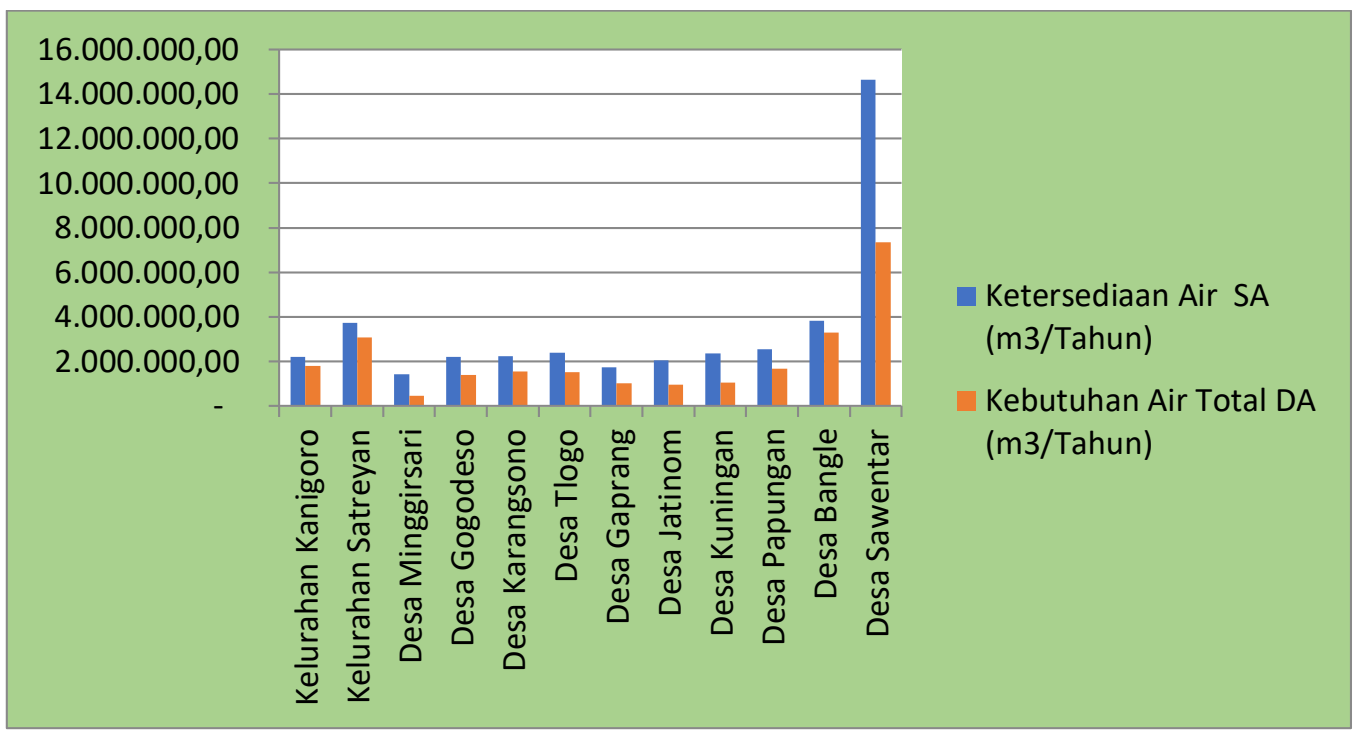

Gambar 5. Daya Dukung Air Kecamatan Kanigoro Tahun 2018

Berdasarkan gambar 5 tersebut, maka daya dukung air di Kecamatan Kanigoro tahun 2018 dalam keadaan surplus di semua wilayah desa/kelurahan nilai ketersediaan air $\left(\mathrm{S}_{\mathrm{A}}\right)$ lebih besar daripada $\mathrm{D}_{\mathrm{A}}$. Surplus air rata-rata di Kecamatan Kanigoro sebesar 39,27\% dengan surplus terbesar di Desa Minggirsari sebesar 66,94\% dan terkecil di Desa Banggle sebesar 14,25\%. Sebagian besar kebutuhan air baku diambil dari sumur baik. Kondisi ini dapat menyebabkan semakin berkurangnya volume ketersediaan air tanah karena masukan air hujan dari daerah resapan / daerah terbuka semakin kecil akibat adanya perubahan penggunaan lahan dari lahan terbuka ke lahan terbangun sehingga menyebabkan mengurangi kemampuan lahan dalam meresapkan air hujan ke dalam tanah.

\section{PEMBAHASAN}

Keberadaan air di bumi berada dalam suatu siklus dengan jumlah air yang relatif tetap yang berlangsung secara terus menerus sehingga dinamakan siklus hidrologi. Dalam siklus hidrologi tersebut terjadi suatu keseimbangan antara masukan dan keluaran air sehingga jumlah air yang ada di bumi selalu tetap. Hanya saja fluktuasi jumlah input dan output tersebut selalu berubah setiap waktu tergantung pada aliran ke dalam (inflow) dan aliran keluar (outflow) di suatu wilayah pada periode waktu tertentu. Sehingga sangat mempengaruhi ketersediaan air yang merupakan kondisi kandungan air tanah yang diperoleh dari proses masukan dan keluaran air pada neraca air (Purbawa dan Wiryajaya, 2009). Dalam menentukan hubungan antara pemanfaatan lahan dan ketersediaan air tanah maka haruslah diketahui daya dukung dukung lahan dan air. Ketersediaan 
lahan dan air menjadi faktor penting dalam Pembangunan perkotaan yang dilakukan dengan tujuan sebagai berikut (Carmon et al, 1997):

1. Meningkatnya jumlah air baik yang meresapa maupun tersimpan ke dalam lapisan di bawah permukaan bumi;

2. Air hujan yang turun ke permukaan bumi semakin banyak yang dapat mereap dan mengisi akifer dengan mengurangi besarnya limpasan air di permukaan sehingga dapat mengurangi banjir serta genangan air di permukaan.

Tutupan lahan merupakan kondisi yang menggambarkan penutup lahan yang nampak di permukaan bumi. Dari tutupan lahan dapat diketahui perubahanperubahan penggunaan lahan yang ada di permukaan bumi. Perubahan penggunaan lahan dalam kurun waktu tertentu, telah menyebabkan berkurangnya daerah resapan dan badan air. Kondisi ini disebabkan berkurangnya kemampuan lahan dalam meresapkan air ke dalam tanah akibat adanya penutupan lahan oleh bangunan-bangunan. Kecamatan Kanigoro sebagai ibukota Kabupaten Blitar sejak tahun 2010 telah mengalami perubahan yang cukup pesat dari daerah pedesaan ke perkotaan berupa perubahan pemanfaatan lahan dari lahan terbuka menjadi lahan terbangun untuk memenuhi perkembangan sebuah kota. Pengaruh perubahan pemanfaatan lahan terhadap daya dukung air di Kecamatan Kanigoro dapat dilihat dari hasil analisis pemanfaatan lahan tahun 2002 dan 2018, kemampuan lahan, perhitungan ketersediaan air, kebutuhan air dan daya dukung air.

Komposisi perubahan pemanfaatan lahan yang terluas tahun 2002-2018 dari sawah menjadi lahan permukiman dapat mempengaruhi kemampuan penyerapan air ke dalam tanah. Pengertian lahan terbuka adalah suatu lahan pada suatu kawasan tanpa adanya bangunan di atas tanah, dan termasuk ruang terbuka hijau (Sadyohutomo, 2009). Berdasarkan pengertian lahan terbuka tersebut, maka penulis mengklasifikasikan pemanfaatan lahan menjadi 2 (dua), yaitu :

a. Lahan terbuka yang terdiri dari badan air, hutan, kebun, lahan kosong, sawah dan perkebunan;

b. Lahan terbangun yang terdiri dari lahan permukiman.

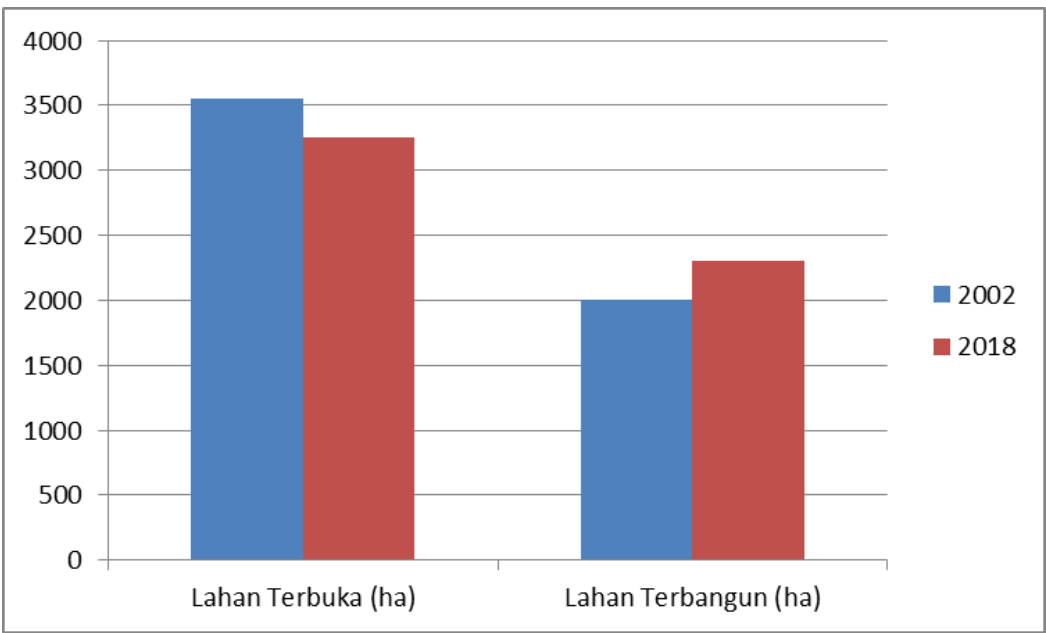

Gambar 6 Perbandingan Luas Lahan Terbuka dan Terbangun Kecamatan Kanigoro Tahun 2002 dan 2018

Berdasarkan gambar 6 tersebut terlihat bahwa di Kecamatan Kanigoro, peruntukan lahan terbuka mengalami penurunan dari tahun $2002-2018$ sebesar

862 BRILIANT: Jurnal Riset dan Konseptual

Volume 5 Nomor 4, November 2020 
2,26\%. Semakin luasnya area permukiman yang dibangun di atas lahan terbuka tersebut akan menyebabkan berkurangnya area resapan air hujan ke dalam tanah (Harris, 2010). Penurunan luas lahan terbuka ini dapat mengakibatkan penurunan kemampuan lahan dalam meresapkan air ke dalam tanah sehingga terjadi peningkatan laju aliran air permukaan.

\section{KESIMPULAN}

Daya dukung ketersediaan air Kecamatan Kanigoro tahun 2018 masih surplus sehingga masih dapat mencukupi kebutuhan air dan terjadinya perubahan pemanfaatan lahan dari lahan terbuka menjadi lahan terbangun yang mengakibatkan semakin besarnya limpasan air sehingga air hujan yang meresap kedalam tanah akan semakin berkurang

\section{SARAN}

Menambah daya resap air hujan dengan memanen air hujan melalui menambah ruang terbuka atau membuat bangunan resapan seperti biopori, sumur resapan, embung, danau atau waduk sehingga air dapat meresap lebih banyak dan lebih lama di dalam tanah, serta memperkuat dan perijinan tata ruang sehingga tetap dapat memenuhi komposisi minimal ruang terbuka hijau sebesar 30\% di setiap wilayah.

\section{DAFTAR RUJUKAN}

Badan Perencanaan Pembangunan Daerah Kabupaten Blitar. 2017. Laporan Akhir Rencana Program Investasi Jangka Menengah (RPIJM) Bidang Cipta Karya Kabupaten Blitar Tahun 2018-2022.

Badan Pusat Statistik Kabupaten Blitar. 2019. Kabupaten Blitar Dalam Angka Tahun 2019.

Badan Pusat Statistik Kabupaten Blitar. 2019. Kecamatan Kanigoro Dalam Angka Tahun 2019.

Carmon, Naomi et al. 1997. Water-Sensitive Urban Planning: Protecting Groundwater. Journal of Environmental Planning and Management, 40(4), 413-434, 1997.

Dinas Pekerjaan Umum dan Penataan Ruang Kabupaten Blitar. 2017. Laporan Akhir Revisi Kajian Lingkungan Hidup Strategis RDTR BWP Kanigoro.

Dinas Lingkungan Hidup Kabupaten Blitar. 2019. Laporan Akhir Daya Dukung Daya Tampung Lingkungan Hidup.

Harris, Soepardi. 2010. Peran Serta Masyarakat Dalam Menjaga Keberlangsungan Air Tanah Di Perkotaan Dengan Sistem Sumur Resapan. Jurnal Ilmiah Faktor Exacta Vol. 3 No. 3 September 2010.

Indarto. 2010. Hidrologi Dasar Teori dan Contoh Aplikasi Model Hidrologi. Jakarta : Penerbit Bumi Aksara.

Irianto, Gatot. 2006. Pengelolaan Sumberdaya Lahan dan Air (Strategi Pendekatan dan Pendayagunaannya). Jakarta : Badan Penelitian dan Pengembangan Pertanian dan Penerbit Papas Sinar Sinanti.

Kodoatie, Robert J. dan Roestam Sjarief. 2010. Tata Ruang Air. Yogyakarta : Penerbit ANDI. 
Purbawa, I Gede Agus dan I Nyoman Gede Wiryajaya. 2009. Analisis Spasial Normal Ketersediaan Air Tanah Bulanan Di Provinsi Bali. Buletin Meteorologi, Klimatologi dan Geofisika, Vol. 5 No. 2 Juni 2009.

Suripin. 2001. Pelestarian Sumber Daya Tanah dan Air. Yogyakarta : Penerbit ANDI

Todd, David Keith dan Mays, Larry W. 2005. Ground Water Hydrology. Edisi Ketiga. New York : John Wiley \& Sons.

Widharyatmo. 2010. Pengaruh Timbal Balik Perkembangan Lingkungan / Tata Ruang Perkotaan Dan Sekitarnya. Journal of Rural Development Volume I No. 2. Agustus 2010. 